\title{
Prospect Conceiving of Joint Research and Development of Shale Gas and Coalbed Methane in China
}

\author{
Shangbin Chen ${ }^{1,2^{*}}$, Yanming Zhu ${ }^{1,2}$, Meng Wang ${ }^{1}$, Wu Li ${ }^{1}$, Huaimeng Wang ${ }^{1}$ \\ ${ }^{1}$ School of Resources and Earth Science, China University of Mining and Technology, Xuzhou, China \\ ${ }^{2}$ Coalbed Methane Resources and Reservoir Formation Process Key Laboratory of Ministry of Education \\ (China University of Mining and Technology), Xuzhou, China \\ E-mail: shangbinchen@163.com
}

Received April 8, 2011; revised April 27, 2011; accepted May 2, 2011

\begin{abstract}
Inspired by successful development of shale gas in USA and influenced by hydrocarbon resources shortage currently, China has strengthened shale gas research and accelerated its exploration process. In order to enrich coalbed methane (CBM) and shale gas geological theory and promote their development process, this paper compared shale gas with CBM in accumulation, distribution, reservoir and production. It expatiated on the background and significance of the combined research and development, and analyzed the geological foundation and future prospects. Our investigation demonstrated that there are many sets of coal-bearing strata in Shanxi formation of Permian system in Ordos in North China, Longtan formation of Upper Permian and Xujiahe formation of Upper Triassic in Southern Yangtze region, Xishanyao formation of Middle Jurassic in Turpan-Hami Basin and Junggar Basin in Northwest China, and Shahezi formation of Cretaceous in Songliao Basin in northeast China. In these regions, shales which are interbeded with coal seams have the characters of big thickness, continuous distribution, high content of organic matter, good parent material and high maturity, accord with the basic geological conditions to format shale gas and CBM reservoir and composite gas reservoir, thus form appropriate regions and layers to carry out joint research and exploration with good prospects for development.
\end{abstract}

Keywords: Shale Gas, Coalbed Methane (CBM), Joint Research and Development, China

\section{Introduction}

The resource of shale gas around the world is $456.2 \times$ $10^{12} \mathrm{~m}^{3}$, approximately occupying $50 \%$ of the unconventional gas resources. Successful development of shale gas in America brings an innovation to natural gas field. Since then, shale gas has become the new favorite of the world's resources. In the year of 2007, there were about 42000 shale gas wells in America and about 60 corporations being involved in the development. They yearly produced $450 \times 10^{8} \mathrm{~m}^{3}$ of gas, occupying $8 \%$ in annually natural gas production. The yield of shale gas increased to $880 \times 10^{8} \mathrm{~m}^{3}$ in 2009 , accounting for about $14 \%$ in natural gas production. It is expected that the rate would reach $16 \%$ in the year of 2011 . The great commercial interests and the significance to energy security guarantee and the ease to oil and gas shortage make the world upsurge of shale gas research [1]. Shale gas resource in China is very rich, although research and exploration started late and still at the stage of exploratory [2-5], it is clear that we have speeded up the process of exploration and development.

As unconventional natural gas resources, we have formed a consensus that shale gas has the similarities with CBM in accumulation mechanism and some aspects [6,7]. But combining them to research and exploration has not been discussed. Only Huang [8] analysed the prospect of shale gas and CBM exploration in Sichuan Basin. Based on the classification of shale which are rich in organic matter, Li [9] proposed further study of overlay forming rules and symbiotic characteristics of shale gas, CBM, tight sandstone gas and many types of natural gas; launching the exploration of many types of natural gas resources; exploring the cost-effective multi-layers commingled developing technology. It is a new issue to effectively develop and use this type of natural gas. Thus, this paper discussed the feasibility of shale gas and CBM combined mining on the basis of the distribution charac- 
teristics, which has some positive significance on cost-effective research and development of shale gas and CBM.

\section{Contrast of Shale Gas and CBM and Their Resources Distribution}

\subsection{Contrast of Shale Gas and CBM}

Shale gas and CBM are both belong to unconventional natural gas, differ from conventional natural gas [10-12]. Creties and Charles [6] detailed analyzed the mechanism of shale gas and CBM, drilling, completing and mining method, calculating resource method, assessment of commercial value, and so on. What's more, they introduced the geological position, production value and exploration method of CBM and shale gas, and the status in other countries. This technical support on CBM and shale gas in America has lasted for more than twenty years. Table 1 lists some features between shale gas, CBM and conventional natural gas. We can conclude from Table 1 that shale gas and CBM have great similarities in reservoir characteristics, distribution, reservoir feature and mining method, which are remarkably different with conventional natural gas.

\subsection{Distribution of Shale Gas and CBM in China}

A new round of nationwide appraisal of CBM resources (East, West, Central, South, Tibet) appraised 42 main coal basins and 121 gas zones. The authors took part in this appraisal, and gained a deep understand of the CBM resource of Songzao mining area in Chongqing province $[13,14]$. This appraisal shows that the CBM resource buried shallower than $2000 \mathrm{~m}$ is $36.81 \times 10^{12} \mathrm{~m}^{3}$ (more than natural gas of $35 \times 10^{12} \mathrm{~m}^{3}$ ), recoverable resources buried shallower than $1500 \mathrm{~m}$ is $10.87 \times 10^{12} \mathrm{~m}^{3}$ (Table 2), and well mining resource whose depth is less than $1000 \mathrm{~m}$ occupies $60 \%$ of recoverable resources nationwide; CBM resource mainly distributes in Carboniferous and Permian of Late Paleozoic, Triassic, Jurassic and Cretaceous of Mesozoic, among these the resources of Mesozoic occupies the most. It occupies more than half of the resources nationwide. Regionally, the resource is mainly concentrated in Ordos, Qinshui, Junggar, Eastern Yunnan-Western Guizhou, Eren, Tuba, Tarim, Tianshan, Hailar basins, the geological resources in these 9 basins are all above $1 \times 10^{12} \mathrm{~m}^{3}[15,16]$. Recently, on the basis of fully referring to the division scheme of basins, basins containing oil and gas, coal basins, Zhao [17] proposed a division scheme which divides the CBM basins according to the coal basins today, and proposed a principle that compositing geological files and geophysical files to determine the borders of CBM basins. He divided mainland China into 3 large regions, 9 subregions and 64 CBM basins (Figure 1(a)), which is more reasonable.

According to the preliminary assessment, the shale gas resource in China reaches up to $100 \times 10^{12} \mathrm{~m}^{3}$ [18], the available resource is $26 \times 10^{12} \mathrm{~m}^{3}$ [19], roughly distributing in 4 large regions, Southern region (Yangtze subregion and South-east subregion), Northern region (Central

Table 1. Contrast in partial features between shale gas, CBM and conventional natural gas (Modified after [6,7]).

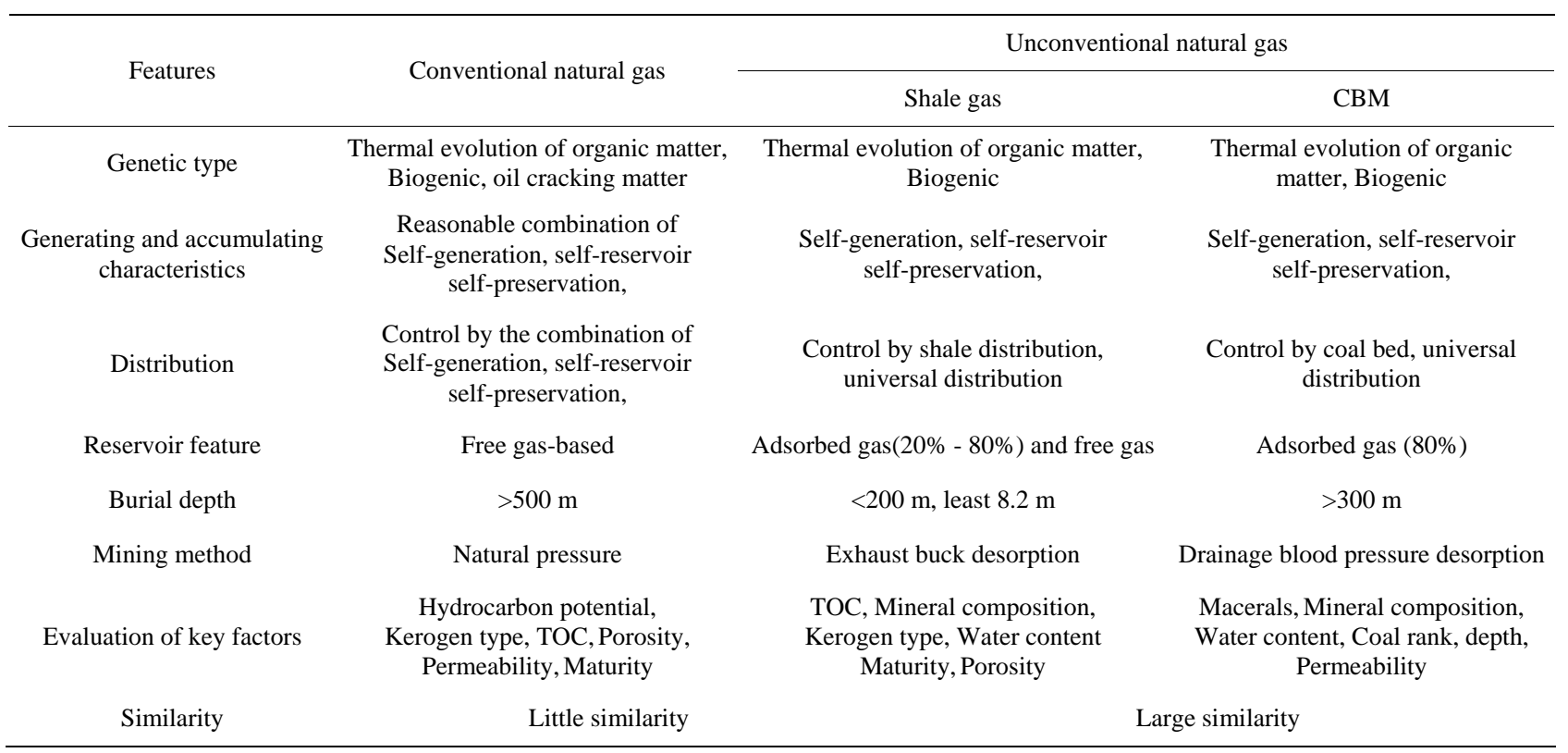


Table 2. Comparison of resource distribution between CBM and shale gas in China.

\begin{tabular}{|c|c|c|c|c|c|c|c|c|c|}
\hline \multirow{2}{*}{ Type } & \multirow{2}{*}{ Zoning } & \multicolumn{2}{|c|}{ Geological resource reserves } & \multicolumn{2}{|c|}{ Recoverable resources } & \multirow{2}{*}{ Type } & \multirow{2}{*}{ Zoning } & \multicolumn{2}{|c|}{ Recoverable resources } \\
\hline & & $\times 10^{12} \mathrm{~m}^{3}$ & Proportion (\%) & $\times 10^{12} \mathrm{~m}^{3}$ & Proportion (\%) & & & $\times 10^{12} \mathrm{~m}^{3}$ & Proportion (\%) \\
\hline \multirow{6}{*}{ CBM } & Northern & 11.32 & 30.8 & 4.32 & 39.7 & & \multirow[b]{2}{*}{ Northern } & \multirow[b]{2}{*}{2.31} & \multirow[b]{2}{*}{8.9} \\
\hline & North-east & 10.47 & 28.4 & 2.00 & 18.4 & & & & \\
\hline & North-west & 10.36 & 28.1 & 2.86 & 26.3 & Shale gas & North-west & 11.18 & 43 \\
\hline & Southern & 4.66 & 12.3 & 1.70 & 15.6 & & Southern & 12.17 & 46.8 \\
\hline & Qinghai-Tibet & 0 & 0 & 0 & 0 & & Qinghai-Tibet & 0.34 & 1.3 \\
\hline & Total & 36 & - & 10.9 & - & & Total & 26 & - \\
\hline
\end{tabular}

(Notes: (a) Recoverable resources of shale gas are according to Zhang et al. [19]; (b) In CBM resource evaluation, the resource of Qinghai-Tibet region is 0 for topographic conditions; (c) The geological resource reserves is depth less than $2000 \mathrm{~m}$, and the recoverable resource is depth less than $1500 \mathrm{~m}$.)

subregion, North-east subregion and East subregion), North-west region (Northern subregion, Southern subregion and Qaidam subregion) and the Qinghai-Tibet region. Southern region mainly develops shale gas of Cambrian, Silurian and Permian. Northern region mainly forms shale gas of Ordovician, Carboniferous and Permian. North-west region mainly forms shale gas of Late Permian and Mesozoic. Qinghai-Tibet region develops marine shale gas of Paleozoic and Mesozoic, but it's only regarded as favorable prospects region for its geographical conditions (Figure 1(b)).

According to the distribution feature of CBM and shale gas resource in China, Carboniferous and Permian system of Late Paleozoic, Triassic, Jurassic, Cretaceous system of Mesozoic and other coal-bearing strata and clay shale can generate and store shale gas and CBM at the same time, the feature of resource distribution has overlapping and compound character.

\section{Significance of Joint Exploring Shale Gas and CBM}

Firstly, CBM in China has developed into the commercialization stage [20-22], but the range is not wide enough, there are plenty of key technical problems have not being overcome yet, which need more extensive research to consummate. Meanwhile, shale researches are started up recently; there are a series of similarities between CBM and shale gas in accumulation, development and resource distribution, etc.

Secondly, as mentioned in 2.2, interbedded shale which are rich in organic matter and coal or thin coal seam are widespread in late Paleozoic and Mesozoic strata in china, satisfying the essential geological condition to carry out the combined research on shale gas and CBM. According to the successful development of shale gas in United States [11,23,24], shale buried in the depth of 183 $2591 \mathrm{~m}$ (the buried depth of east basin between Delaware and Texas is 3450 - $5562 \mathrm{~m}$ and 3352 - $3962.4 \mathrm{~m}$ respectively) in the main basin (Fort Worth, Appalachian, Michigan, Illinois and San Juan), mostly less than 1500 $\mathrm{m}$, are relatively shallow and approaching to the rich layer of CBM exploitation. And now in the current research shale samples are mostly from surface or near the surface [9], both have geological, exploitable and experimental basis to combined research and development.

Thirdly, for shale gas is in infancy stage in china, there are a lot of limitations: drilling wells directly conducted for shale gas exploration (air testing, well testing, etc.) are very few; research data are primarily acquired from conventional oil \& gas, CBM, and solid mineral exploration data [9]. First shale gas coring shallow well in China (designed and implemented by RIPED), Changxin-1 well in Yibin, Sichuan Province, was successfully finished on November 26, 2008, for the Silurian shale core samples and test data [25]. The first domestic shale gas exploration wells started in Lianhu town Pengshui Miao and Tujia Autonomous County of Chongqing, by Ministry of Land and Oil and Gas Resources Strategic Research Centre and China University of Geosciences (Beijing), on November 28, 2009, indicates the formal implementation of shale gas exploration in china. For only two wells currently, it is very weak for accurate assessment of shale gas and related research.

Finally, shale gas has a lot in common with conventional hydrocarbon resources in generating, and the data of conventional oil and gas source rocks has a great reference, but in reservoir, especially in mining technology, there are great differences. So it's necessary to learn the experience and skills of CBM, especially in reservoir requirements, development of fracturing and horizontal well technology, which lay a perfect foundation for the combined research on shale gas and CBM. Meanwhile, CBM research in China has made a significant achievement as well as commercial development [20,22], so the combined research can learn from home and aboard, par 


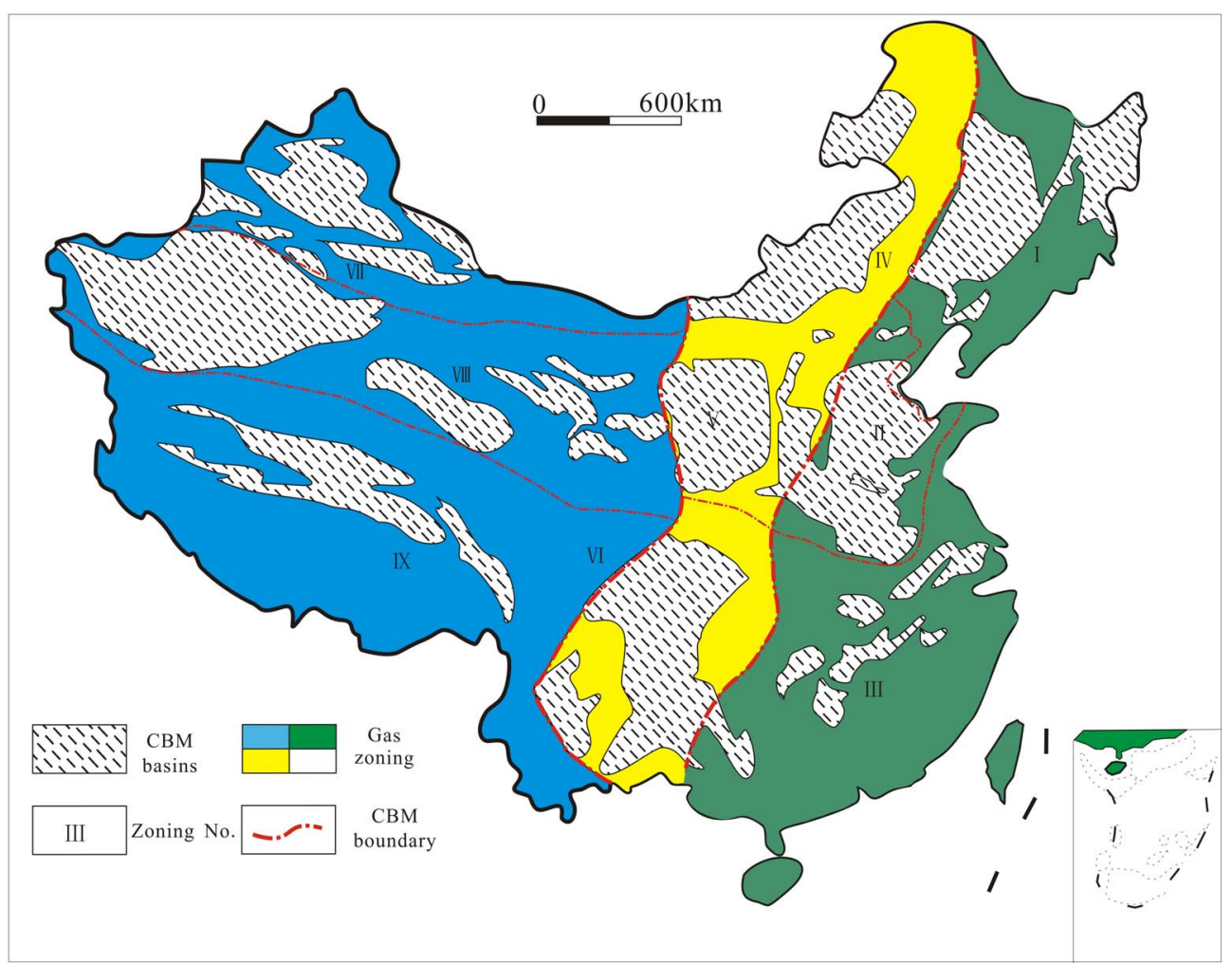

(a)

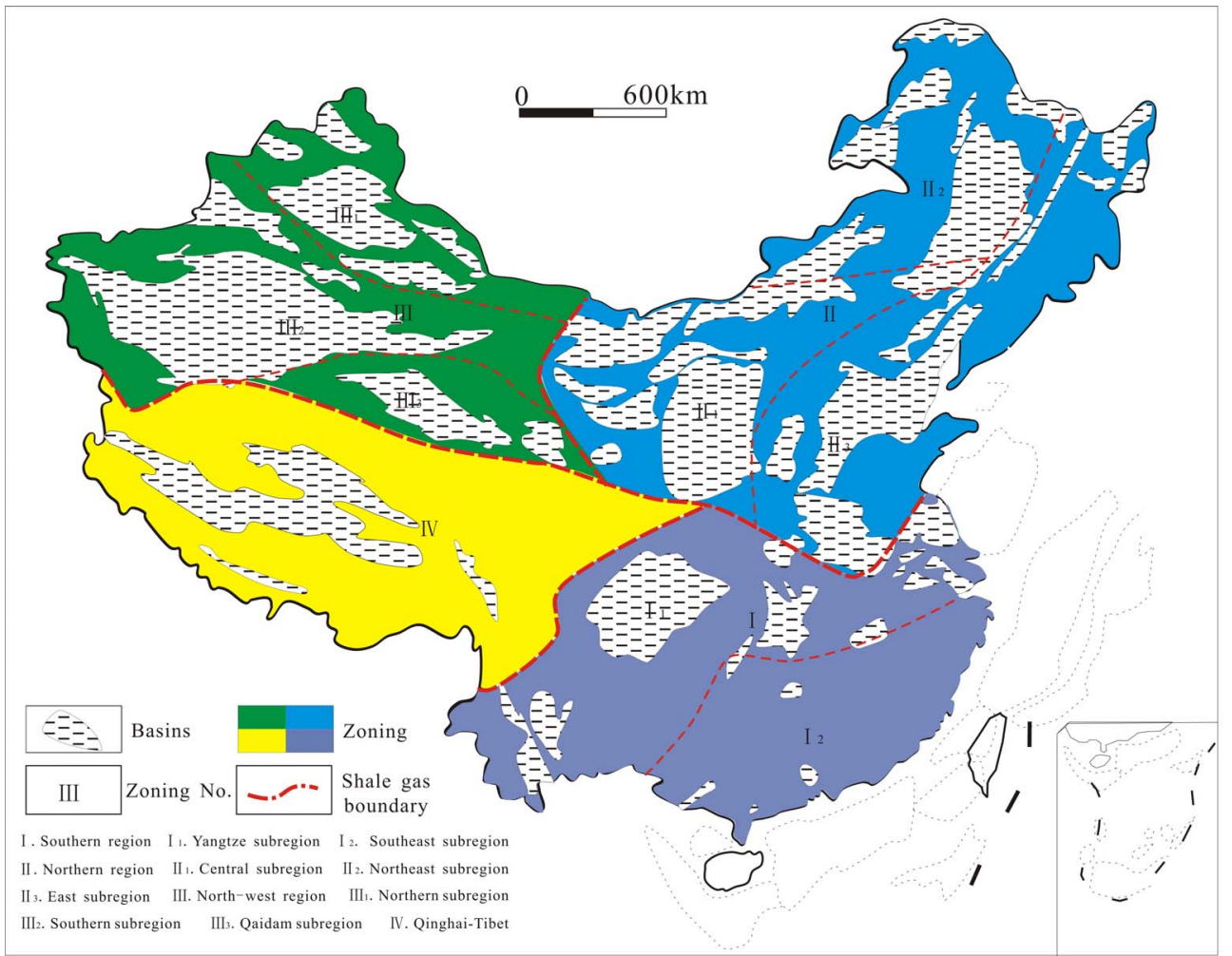

(b)

Figure 1. Resource distribution of CBM and shale gas in China. (a) CBM basins in China (Zhao et al. [17]); (b) Shale gas resource distribution in China (Zhang et al. [19]). 
ticularly the experience of CBM in China to shorten the research course.

Therefore, provided the geological distribution of the organic-rich shale, the initial stage of shale research and the achievement of CBM, combined research is considered to share pipe network and experience, save costs, shorten the course and be economically feasible. If the combined research and exploit at certain regions or layers goes well, it will be significant both in theory and practice.

\section{Geological Settings and Prospects of Joint Research on Shale Gas and CBM}

Research on the strata data indicates that coal-bearing strata in different geological eras and organic-rich shale is widely developed in northern, northeast, northwest, southern margin of Yangtze Platform. This makes it possible to do the joint research and development on shale gas and CBM.

Shale of Qingshankou and Shahezi formation of Cretaceous in Northeast Basin is constituted by gray, dark gray mudstone, silty mudstone, gray, dark gray siltstone, with stable recoverable coal seams. It is mainly hydrocarbon source rocks in the Basin, with organic carbon content of $1.99 \%$ on average, high abundance of organic matter, and potential to form shale gas and CBM simultaneously. Analyzing on deep natural gas in Song-Liao basin [26] also proved widespread of coal-type gas in the basin.

Shuixigou group of Middle-Lower Jurassic (including Badaowan formation in the lower, Sangonghe formation in the middle, upper part of Xishanyao formation of Middle Jurassic) developed in Northwestern Junggar Basin and Turpan-Hami Basin is a set of major coalbearing strata, with abundant CBM resource. The thickness of dark shale and carbonaceous shale here is accumulated to 100 - $800 \mathrm{~m}$, more than $600 \mathrm{~m}$ on average, and total organic carbon content is $1.3 \%$ - $20 \%$, which are benefit for generating and accumulating of shale gas [19]. Study [27] shows that there are coal series and coal oil of the carbonaceous shale from lower Jurassic (Xishanyao coal and Badaowan coal) in Turpan-Hami Basin. Therefore the whole set also has the required conditions to form shale gas and CBM simultaneously.

Qaidam Basin is benefit for accumulating shale gas because of the thick strata of Quaternary, shallow burial depth, medium maturity, good reservoir properties and gas anomaly in general. Meanwhile, Jurassic in the northern margin, of which the source rocks are also mature, is beneficial for shale gas distribution, especially the southern zone Kunteyi-Ibei depression of 400 - 800 $\mathrm{m}$ thick dark shale, northern zone Saishiteng-Yuka depression of 200 - 400 m thick coal and dark shale, East- ern, in which Middle Jurassic system developed, dark shale thickness is more than $400 \mathrm{~m}$ [28], are the favorable areas to generate shale gas and CBM.

Shanxi Formation of Carboniferous and Permian system is a set of sea-land cross continental coal-bearing sedimentary of gray, black mudstone, carbonaceous mudstone, shale and coal seam, which is widely distributed in Ordos, Qinshui basins of north China (Shanxi, Hebei, Henan and Shandong province). The coal seams here are thick and CBM resources are abundant. Dark shale of Paleozoic Ordovician, Carboniferous and Permian system in this region is well developed with a thickness of $100-400 \mathrm{~m}$. Content of organic matter is high, and the maturity is between mature and high mature. All of the above provides a basic condition for shale gas formation. Besides, the gas in shale section in many drilling wells is abnormal.

Longtan formation of Upper Permian is extensively developed in Southern Yangtze region, argillaceous source rocks and coal source rock is $100-300 \mathrm{~m}$ thick, partial $600 \mathrm{~m}$, organic matter content holds $2 \%$ - 5\%, partial high to 21\% [29]; CBM resource is rich in some part of regions, such as Qianxi [13], Songzao [14]. In the Northwest area of Sichuan Basin, Xujiahe formation of Upper Triassic is widely developed, sea-land cross coal-bearing deposits are $600 \mathrm{~m}$ thick on average with high organic carbon content. These coal-bearing strata satisfy the formation conditions of CBM and shale gas.

The analysis on shale gas types and conditions (Table 3) by Zhang et al. [19], and CBM resource evaluation results show that Shanxi formation of Late Paleozoic Permian in North China (Ordos Basin), Longtan Formation of Upper Permian of Late Paleozoic and Xujiahe formation of Upper Triassic of Mesozoic in South China(Yangtze region), Shuixigou Group (Xishanyao formation) of Middle-Lower Jurassic of Mesozoic in Turpan-Hami Basin and Junggar Basin, and Qingyi period and Shahezi formation of Mesozoic of Cretaceous in Songliao basin contain unequal thickness coal strata; of them the coal seam and shale rich in organic matter are thick. These regions, with rich organic carbon content, high maturity, possess the basic conditions to generate shale gas and methane simultaneously, become the favorable areas and layers to carry out combined research and development of shale gas and CBM.

This study also proves that because of the sea-land cross backdrop, the single-layer of coal interbedded shale which is rich in organic matter is too thin to mining respectively, thanks to the high total organic carbon content and a higher degree of thermal evolution, the shale have a certain resource potentiality, and usually exists near CBM or tight sand gas etc. to form overlay multigas accumulation [9]. Despite coal series of Longtan 
Table 3. Potentiality of combined research and development of shale gas and CBM in China.

\begin{tabular}{|c|c|c|c|c|c|c|}
\hline Main basin & Formation & Shale section & Shale thickness (m) & TOC (\%) & Ro (\%) & $\begin{array}{c}\text { Whether with } \\
\text { coal or not }\end{array}$ \\
\hline Qaidam & Quaternary & Qigequan formation & $0-800$ & $0.3-0.6$ & $0.2-0.5$ & \multirow[b]{4}{*}{ Coal-bearing } \\
\hline Bohai Sea Gurf & Paleogene & Shahejie & $230-1800$ & $0.3-33.0$ & $0.3-1.0$ & \\
\hline \multirow[b]{2}{*}{ Songliao } & \multirow[b]{2}{*}{ Cretaceous } & Green section of Qingshankou & $>100$ & 2.2 & $0.7-3.3$ & \\
\hline & & Shahezi formation & $100-350$ & $0.7-1.5$ & $1.5-3.9$ & \\
\hline Chiangtang & Middle Jurassic & Xiali formation & $400-600$ & $0.3-6.2$ & 1.4 & \\
\hline Tuha & Middle, Lower Jurassic & Shuixigou group & $50-600$ & $1.3-20.0$ & $0.4-1.1$ & Coal-bearing \\
\hline Zhungeer & Middle Jurassic & Xishanyao formation & $350-400$ & $0.2-6.4$ & $0.6-2.5$ & Coal-bearing \\
\hline Sichuan & Upper Triassic & Xujiahe formation & $150-1000$ & $1.0-4.5$ & $1.0-2.2$ & Coal-bearing \\
\hline Ordos & Triassic & Yanchang formation & $50-120$ & $0.6-5.8$ & $0.7-1.1$ & \\
\hline Southern (Yangtze) & Upper Permian & Longtan formation & $20-2000$ & $0.4-22.0$ & $0.8-3.0$ & Coal-bearing \\
\hline Ordos & Carboniferous-Permian & Shanxi formation & $60-200$ & $2.0-3.0$ & $>1.3$ & Coal-bearing \\
\hline Southern (Yangtze) & Lower Silurian & Longmaxi formation & $30-100$ & $0.5-3.0$ & $2.0-3.0$ & \\
\hline Southern (Yangtze) & Under the Cambrian & Qiongzhusi formation & $20-700$ & $1.0-4.0$ & $3.0-6.0$ & \\
\hline
\end{tabular}

formation of Permian system in eastern Yunnan and western Guizhou in south China may widely develop multi-layer independent CBM system [30], it is accompany with the rich organic matter carbonaceous mudstone, silt mudstone. In certain conditions, it may form multi-bed methane and shale gas reservoir; in addition, Longtan formation has buried in Indosinian, uplifted and eroded in Yanshan, uplifted in Himalayan, then it buried shallower [31], in a word, it's an ideal area for combined research and development.

\section{Conclusions}

Comparing shale gas with CBM on accumulation and distribution, studying the distribution of coal and shale rich in organic matter in major coal-bearing basins in China, following conclusions can be obtained:

1) Shale gas and CBM have similarities in accumulation, distribution, storage and exploitation, overlapping and compound in resources distribution, which form the basic conditions to combined research and development. 2) Implementation of combined research and development of shale gas and CBM is helpful for overcoming the problems such as the lack of current drilling, specialized information and condition restrictions like depth etc.. It is significant to reduce the shale gas exploration from research to commercial development and reference the experience from successfully exploitation in CBM.

3) Many formations are sea-land cross and continental deposits, organic-rich shale and coal seams of layers/ Inter-layer, such as Shanxi formation of Carboniferous-
Permian system of Late Paleozoic in north China, Longtan formation of the Upper Permian system in Southern Yangtze Region, Xujiahe formation of the Upper Triassic in Mesozoic in south China and Xishanyao formation of Middle Jurassic in the northwest China. All the above features form the geological conditions on combined research on shale gas and CBM which has favorable resource potentiality and development prospects.

\section{Acknowledgements}

This study was jointly supported by Natural Science Foundation of China (No. 41072117), the Major State Basic Research Development Program of China (973 Program) (No. 2009CB219605), and Major Program of National Natural Science Foundation of China (No. 40730422). Wu would like to give sincere thanks for the continuous supply of funds.

\section{References}

[1] J. P. Pan, "Shale Gas Development and Future Prospects on the Promotion of the Development of Shale Gas Resources," International Petroleum Economics Monthly, Vol. 11, 2009, pp. 12-15.

[2] J. C. Zhang, H. K. Nie, B. Xu, et al., “Geology Condition of Shale Gas Accumulation in Sichuan Basin," Natural Gas Industry, Vol. 28, No. 2, 2008, pp. 151-156.

[3] J. Z. Li, D. Z. Dong, G. S. Chen, et al., "Prospects and Strategic Position of Shale Gas Resources in China," Natural Gas Industry, Vol. 29, No. 5, 2009, pp. 11-16. 
[4] R. F. Pan and X. S. Huang, "Shale Gas and Domestic Exploration Prospect," China Petroleum Exploration, Vol. 14, No. 3, 2009, pp. 1-5.

[5] S. B. Chen, Y. M. Zhu, H. Y. Wang, et al., "Research Status and Trends of Shale Gas in China," Acta Petrolei Sinica, Vol. 31, No. 4, 2010, pp. 689-694.

[6] D. J. Creties and M. B. Charles, "Coalbed and Shale Gas Reservoirs,” Journal of Petroleum Technology, Vol. 60, No. 2, 2008, pp. 92-99.

[7] H. Y. Jiang, X. M. Song, X. X. An, et al., "Current State and Outlook of Exploration and Development of the Shale Gas Resources in the World," Petroleum Geology \& Oilfield Development in Daqing, Vol. 27, No. 6, 2008, pp. 10-14.

[8] J. Z. Huang, "Exploration Prospect of Shale Gas and Coal-Bed Methane in Sichuan Basin,” Lithologic Reservoirs, Vol. 21, No. 2, 2009, pp. 116-120.

[9] Y. X. Li, H. K. Nie and P. Y. Long, "Development Characteristics of Organic-Rich Shale and Strategic Selection of Shale Gas Exploration Area in China,” Natural Gas Industry, Vol. 29, No. 12, 2009, pp. 115-118.

[10] B. E. Law and J. B. Curtis, "Introduction to Unconventional Petroleum Systems," American Association of Petroleum Geologists Bulletin, Vol. 86, No. 11, 2002, pp. 1851-1852.

[11] J. B. Curtis, "Fractured Shale-Gas Systems," American Association of Petroleum Geologists Bulletin, Vol. 86, No. 11, 2002, pp. 1921-1938.

[12] W. B. Ayers Jr., "Coalbed Gas Systems, Resources, and Production and a Review of Contrasting Cases from the San Juan and Powder River Basins,” American Association of Petroleum Geologists Bulletin, Vol. 86, No. 11, 2002, pp. 1853-1890.

[13] Y. Qin, S. X. Sang, X. H. Fu, et al., "Potentials of CBM Resources in Key Coal Mining Areas in China and Some Theoretical Problems in Resources Evaluation," China Coalbed Methane, Vol. 3, No. 4, 2006, pp. 17-20.

[14] S. B. Chen, Y. M. Zhu, X. H. Wang, et al., "Study on Coal Bed Methane Deposit Features of Yangchatan Coalfield in Songzao Mining Area,” Coal Science and Technology, Vol. 36, No. 8, 2008, pp. 91-95.

[15] C. B. Che, H. L. Yang, F. B. Li, et al., "Exploration and Development Prospects of Coal Bed Methane (CBM) Resources in China," China Mining Magazine, Vol. 17, No. 5, 2008, pp. 1-4.

[16] C. L. Liu, J. Zhu, C. B. Che, et al., "Methodologies and Results of the Latest Assessment of Coalbed Methane Resources in China,” Natural Gas Industry, Vol. 29, No. 11, 2009, pp. 140-132.

[17] J. Z. Zhao, L. J. Song and B. H. Shi, "Divisional Principles and Projects of Coalbed Methane Basin in Mainland China,” Acta Geologica Sinica, Vol. 82, No. 10, 2008, pp. 1402-1407.

[18] H. Y. Wang, J. M. Li, Q. Zhao, et al., "Resources and Development of New Energy in China," Acta Petrolei
Sinica, Vol. 30, No. 3, 2009, pp. 469-474.

[19] J. C. Zhang, S. L. Jiang, X. Tang, et al., "Accumulation Types and Resources Characteristics of Shale Gas in China,” Natural Gas Industry, Vol. 29, No. 12, 2009, pp. 109-114.

[20] J. P. Ye, "Advances in Exploration and Development of Coalbed Methane in China: A Review," Geological Bulletin of China, Vol. 25, No. 9-10, 2006, pp. 1074-1078.

[21] Y. Qin and A. G. Chen, "CBM Exploration and Exploitation Advances and Trend in China," Coal Geology of China, Vol. 19, No. 1, 2007, pp. 26-29.

[22] K. Qian, Z. S. Shi, S. G. Lin, et al., "Industrialization Progression and Development Suggestions for Coalbed Methane of China,” Natural gas geosciences, Vol. 20, No. 6, 2009, pp. 831-840.

[23] D. F. Martineau, "History of the Newark East Field and the Barnett Shale as a Gas Reservoir," AAPG Bulletin, Vol. 91, No. 4, 2007, pp. 399-403. doi:10.1306/intro910407

[24] D. M. Jarvie, R. J. Hill, T. E. Ruble, et al., "Unconventional Shale-Gas Systems: The Mississippian Barnett Shale of North-Central Texas as One Mondel for Thermogenic Shale-Gas Assessment," American Association of Petroleum Geologists Bulletin, Vol. 91, No. 4, 2007, pp. 475-499. doi:10.1306/12190606068

[25] S. J. Wang, L. S. Wang, J. L. Huang, et al., “Accumulation Conditions of Shale Gas Reservoirs in Silurian of the Upper Yangtze Region,” Natural Gas Industry, Vol. 29, No. 5, 2009, pp. 45-50.

[26] X. Luo, F. J. Sun, M. L. Shao, et al., “Geochemistry of Deep Coal-Type Gas and Gas Source Rocks in Songliao Basin," Petroleum Exploration and Development, Vol. 36, No. 3, 2009, pp. 339-346.

[27] K. M. Cheng, Y. Xiong, X. M. Zeng, et al., "Coal into Hydrocarbons in Turpan-Hami Basin,” Acta Petrolei Sinica, Vol. 23, No. 4, 2002, pp. 13-17.

[28] D. Y. Cao, W. F. Zhan, T. J. Liu, et al., "Tectonic Divisions and Distribution Rules for Coal Measures in Northern Qaidam Basin,” Geotectonica et Metallogenia, Vol. 31, No. 3, 2007, pp. 322-327.

[29] D. G. Liang, T. L. Guo, L. Z. Bian, et al., "Some Progress on Studies of Hydrocarbon Generation and Accumulation in Marine Sedimentary Regions, Southern China (Part1): Distribution of Four Suits of Regional Marine Source Rocks,” Marine Petroleum Geology, Vol. 13, No. 2, 2008, pp. 1-16.

[30] Y. Qin, M. H. Xiong, T. S. Yi, et al., “On Unattached Multiple Superposed Coalbed-Methane System: In a Case of the Suigonghe Syncline, Zhijin-Nayong Coalfield, Gui-zhou," Geological Review, Vol. 54, No. 1, 2008, pp. 65-69.

[31] Y. M. Zhu, H. Zhao, Q. L. Yan, et al., "Tectonic Evolution and CBM Reservoir Formation in Wulunshan Minefield, Guizhou,” Coal Geology of China, Vol. 20, No. 10, 2008, pp. 38-41. 